\title{
Foliar disease infection on some forest trees
}

A Singh*ׁ, S Bhatnagar, S Singh \& LS Rathore

*Lachoo Memorial College of Science and Technology Shastri Nagar, Jodhpur

Forest Protection Division, Arid Forest Research Institute, New Pali Raod, Jodhpur

Corresponding author: Ajay Singh, Email: shiwani.bhatnagar@gmail.com

Copyright (C2017 Singh et al., This is an open access article published under the terms of the Creative Commons Attribution License, which permits unrestricted use, distribution, and reproduction in any medium, provided the original work is properly cited.

Preferred citation for this article: Singh A, Bhatnagar S, Singh S \& Rathore LS. 2017. Foliar disease infection on some forest trees. Journal of Agriculture and Ecology, 3: 38-41; http://doi.org/10.53911/JAE.2017.3106.

\section{Abstract}

In a routine survey foliar disease causing fungi were identified as Phytopthora sp. on leaves of Bauhinia varigata, Alternaria sp. on Cordia dichotoma, Helminthosporium sp. and Alternaria sp. on leaves of Azadirachta indica, Helminthosporium sp on leaves of Pterocarpus santalims Alternaria sp. on Ziziphus mauritiana as well as Eagle marmelos and Fusarium sp. on Acacia leucophloea leafs.

Key words: foliar disease, forest trees, fungi

\section{Introduction}

Foliar diseases caused by fungi are a serious problem in forest regeneration and sometimes fungi may cause a heavy mortality in nursery. Many fungal pathogens are carried over through seeds into forest nurseries and become established on seedlings. Apart from these seed borne fungal pathogens, soil borne fungal pathogen have also been shown to be devastating by attacking on young seedlings in forest nursery. Diseases are one of the important limiting factors in the production of forest seedlings within nurseries. Environmental conditions within nurseries are often ideal for the proliferation of disease-causing pathogens. Keeping in view, the present work was done on foliar diseases associated with trees in AFRI Nursery and AFRI Campus. 


\section{Materials and method}

\section{Collection of foliar disease samples of some forest trees}

Infected leaves were collected from forest trees viz., Acacia leucophloea, Cordia dichotoma, Pterocarpus santalinus, Ziziphus mauritiana, Azadirachta indica, Eagle marmelos, and Bauhinia varigata.

\section{Isolation and Identification of fungus}

Samples of seeds and leaves of plants/trees were collected from nursery and campus of AFRI, Jodhpur and brought to laboratory in polythene bags to avoid aerial contaminations. The Agar plate method as recommended by International Seed Testing Association (1966) was performed for isolation of mycoflora associated with leaves. Pieces of leaves surface were sterilized with $0.01 \%$ sodium hypochloride and then washed with sterilized water. These were incubated on PDA medium in Petri dishes and incubated for 7-10days at $24-25{ }^{0} \mathrm{C}$. Microbial colonies developing from leaves were isolated and identified. Slides of spores were prepared after staining with cotton blue and mounted on a glass slide. The slides were examined under microscope and the causal organism was identified with help of book viz., Introduction to Fungi by Webster \& Weber (2007).; illustrated Genera of Imperfect fungi by H.L. Barnett \& Barry B. Hunter (1972) and Proceeding: DFID Rice-Wheat soil Health Project Mycology and Nematology workshop by Bridge et al. (2001).

\section{Results and Discussion}

Infected leaves from forest trees viz., Acacia leucophloea, Cordia dichotoma, Pterocarpus santalinus, Ziziphus mauritiana, Azadirachta indica, Eagle marmelos, and Bauhinia varigata were collected and the pathogen was culture on PDA media. Isolated fungus were identified as Phytopthora sp. on leaves of Bauhinia varigata, Alternaria sp on Cordia dichotoma, Helminthosporium sp and Alternaria sp on leaves of Azadirachta indica, Helminthosporium sp on leaves of Rakt chandan (Pterocarpus santalims) Alternaria sp on Ziziphus mauritiana and Eagle marmelos and Fusarium sp on Acacia leucophloea leafs. Diseases are a serious problem in forest regeneration and important limiting factors in the 
production of forest seedlings within nurseries. Therefore, it very important to identify foliar disease of forest trees so that infection can be checked at initial level and management strategy could be prepared to deal with in case of epidemics.

Sankaran et al. (1988) during a routine survey of nurseries and plantations of Xylia xylocarpa, Bombax ceiba, Terminalia bellerica, Azadirachta indica and Pterocarpus indicus at Peechi, leaf spot diseases caused by: the Colletotrichum gloeosporioides on A. indica and T. bellirica; G. cingulata on $B$. malabaricum and $X$. xylocarpa; and Cylindrocladium quinqueseptatum on P. indicus. Bhat \& Hegde (1988) reported 33 fungal pathogens (26 genera) causing disease on 33 forest plants in a survey of forest nurseries and suburbs of Dharwad. The most common pathogen was Colletotrichum gloeosporioides.

Singh \& Bhalla (2000) collected infected samples from forests of Vindhyan region, Uttar Pradesh and described four new species of Pseudocercospora occurring on Cassia sophora (C. sophera), Cocculus hirsutus, Eucalyptus sp. and Woodfordia sp., respectively.

Mohanan (1988) recorded leaf blight of 1 to $2 \mathrm{yr}$ old seedlings of $P$. pinnata in an experimental plot at Vazhachal (Chalakudy Forest Division) which was caused by Asperisporium pongamia and a leaf spot by Urohendersonia pongamia.

Harsh et al. (1989) briefly reported for foliage diseases caused by 14 fungal pathogens in the nurseries of Madhya Pradesh. Mehrotra (1990) described about foliar diseases caused by $R$. solani in forest nurseries. Maji et al. (2012), observed that mulberry varieties were affected with foliar diseases viz powdery mildew, leaf rust, Myrothecium leaf spot, and Pseudocercospora leaf spot. Mehrotra et al. (2004) recorded leaf blight, a new disease of Bombax ceiba caused by Ascochyta bombacina, from New Forest, Dehra Dun, Uttar Pradesh, India. Dadwal et al. (2007) described a leaf spot and top dying disease of Ailanthus excelsa Roxb. caused by Colletotrichum dematium.

\section{References}

Barnett HL \& Hunter BB. 1972. Illustrated Genera of Imperfect fungi. $3^{\text {rd }}$ edition. Burges Publishing Company, 1-241. 
Bhat MN \& Hegde RK. 1988. Studies on foliar fungal diseases of forest crops in and around Dharwad. Plant Pathology Newsletter, 6 (1-2): 37.

Bridge J, Kinsey G \& Livingstone S. 2001. In Proceeding: DFID Rice-Wheat soil Health Project Mycology and Nematology workshop. Organized by GBPUAT, Pantnagar, India, 21-31 March.

Dadwal VS, Bhartiya S \& Patel P. 2012. Seed mycoflora of some forest tree species and their control with bioagents. Journal of Tropical Forestry, 28(1/2):73-78.

International seed testing association 1966. International Rules of Seed Testing. Proceeding of International Seed Testing Association, 32: 565-589.

Maji MD, Das C, Rajkhowa G \& Bajpai AK. 2012. Evaluation of some elite mulberry varieties to foliar diseases under Jorhat condition. Bulletin of Indian Academy of Sericulture, 16(1): $43-48$.

Mehrotra MD. 1990. Rhizoctonia solani, a potentially dangerous pathogen of khasi pine and hardwoods in forest nurseries in India. European Journal of Forest Pathology, 20(6-7): 329-338.

Mehrotra MD. 1992. Rhizoctonia leaf spotting and blight of Michelia champaca, a new nursery disease and its management. Indian Forester, 118(3): 227-229.

Mohanan C. 1988. Foliar diseases of Pongamia pinnata caused by Asperisporium pongamiae and Urohendersonia pongamiae in Kerala. Indian Journal of Forestry, 11(3): 202-203.

Singh SK \& Bhalla K. 2000. New Pseudocercospora species causing foliar diseases in plain forests of Vindhya region in India. Indian Phytopathology, 53 (4): 399-403.

Sankaran KV, Florence EJM \& Sharma JK. 1988. Foliar diseases of some forest trees in Kerala - new records. Indian Journal of Forestry, 11(2): 104-107.

Webster J \& Weber R. 2007. Introduction to Fungi.2 $2^{\text {nd }}$ edition, Cambridge University Press.p.1-817. 